\title{
Kondisi Terkini Presentase Tutupan Terumbu Pada Masa Pandemi Covid-19 di Gili Air, Taman Wisata Perairan Gili Matra, Nusa Tenggara Barat
}

\section{The Current Condition of the Coral Reef Cover Percentage during the Covid-19 Pandemic in Gili Air, Gili Matra Marine Protected Area, West Nusa Tenggara}

\author{
Nurliah Buhari*, Mahardika Rizqi Himawan, Edwin Jefri, Paryono, \\ Ibadur Rahman, Ayu Adhita Damayanti
}

Program Studi Ilmu Kelautan, Jurusan Perikanan dan Ilmu Kelautan, Fakultas Pertanian UNRAM, Nusa Tenggara Barat, INDONESIA. Tel. +62-0370 621435, Fax. +62-0370 640189 ${ }^{1}$

*corresponding author, email: nurliah.buhari@unram.ac.id

Manuscript received: 12-14-2021. Accepted: 21-12-2021:

\begin{abstract}
ABSTRAK
Kawasan Konservasi Nasional Taman Wisata Perairan Gili Matra mempuyai dua target konservasi yaitu target biokologis dan target sosial, budaya dan ekonomi. Ekosistem terumbu karang selain menjadi target konservasi juga menjadi daya tarik wisatawan untuk berkunjung. Penelitian ini dilakukan untuk mengetahui kondisi ekosistem terumbu karang untuk dijadikan dasar pengelolaan kawasan konservasi. Penelitian dilakukan dengan mengumpulkan data terumbu karang baik melalui survei maupun data sekunder dari hasil penelitian sebelumnya. Survei terumbu karang menggunakan metode standar Line Intercept Transect. Hasil survei menunjukkan bahwa kondisi terumbu karang dalam zona pemanfaatan lebih baik dari zona inti. Tutupan karang hidup di zona pemanfaatan mencapai $71 \%$ sehingga dikategorikan baik, sedangkan di zona inti hanya mencapai $8 \%$ sehingga termasuk kategori jelek. Terumbu karang di zona inti tidak mampu melakukan recovery meskipun jumlah wisatawan berkurang selama pandemic Covid-19. Oleh karena itu, lokasi zona inti di Gili Air perlu dievaluasi lebih lanjut agar efektifitas pengelolaan TWP Gili Matra dapat ditingkatkan.
\end{abstract}

Kata kunci: terumbu karang; gili matra; konservasi

\begin{abstract}
Gili Matra Aquatic Tourism Park has two conservation targets, namely biological targets and social, cultural and economic targets. Coral reef ecosystems, apart from being a conservation target, are also an attraction for tourists to visit. This research was conducted to determine the condition of the coral reef ecosystem to be used as the basis for the management of conservation areas. The research was conducted by collecting coral reef data either through surveys or secondary data from the results of previous studies. Coral reef survey using the standard Line Intercept Transect method. The survey results show that the condition of coral reefs in the utilization zone is better than the core zone. Live
\end{abstract}


coral cover in the utilization zone reached $71 \%$ so it was categorized as good, while in the core zone it only reached $8 \%$ so it was categorized as bad. Coral reefs in the core zone are unable to recover even though the number of tourists has decreased during the Covid-19 pandemic. Therefore, the location of the core zone on Gili Air needs to be evaluated further so that the effectiveness of Gili Matra TWP management can be improved.

Key words: coral reefs; Gili Matra; Conservation

\section{PENDAHULUAN}

Ekosistem terumbu karang merupakan salah satu ekosistem pesisir yang bernilai tinggi. Berdasarkan estimasi dari beberapa penelitian sebelumnya yang dikutip oleh Burke et al (2002) bahwa potensi terumbu karang yang sehat pertahun per km2 sebesar US\$ $43.000-520.000$. Nilai tersebut dihitung dari berbagai fungsi dan manfaat terumbu karang baik secara ekologi maupun secara economi. Ekosistem terumbu karang menjadi habitat bagi banyak biota laut yang merupakan sumber keanekaragaman hayati, tempat memijah, mencari makan, dan berlindung bagi ikan-ikan (LIPI P2O, 2018; McCook et al., 2009).

Kerusakan terumbu karang dapat terjadi baik secara alami maupun karena anthropogenic (Dahuri et. al., 1996). Namun beberapa penelitian menegaskan bahwa penyebab utama kerusakan terumbu karang di Indonesia karena anthropogenic, seperti penggunaan alat tangkap yang merusak (Wilkinson, 2000; Pet-Soede et al., 2000).

Berdasarkan fakta tersebut, maka diperlukan suatu upaya konservasi yang dapat efektif mengurangi tekanan sumberdaya. Salah satu bentuk upaya konservasi adalah penetapan kawasan konservasi laut. Menurut Salm et al (2000) bahwa kawasan konservasi laut dapat membantu mewujudkan tiga tujuan utama dari konservasi sumberdaya alam seperti yang tercantum dalam the World Conservation Strategy, yaitu (1) mempertahankan proses ekologi yang penting dan sistem pendukung kehidupan; (2) mempertahankan keanekaragaman genetik dan; (3) menjamin pemanfaatan spesies dan ekosistem yang berkelanjutan. Hal tersebut dapat tercapai karena kawasan konservasi laut dapat memberikan perlindungan bagi habitat, memperbaiki kondisi biologi yang ada di dalamnya dan dapat mengurangi overfishing (Agardy et al., 2003).

Kawasan konservasi laut mempunyai banyak tipe dan kategori (PP No. 60 Tahun 2007; Permen KP No. 17 Tahun 2008). Salah satunya adalah Taman Wisata Perairan yang berada dibawah pengelolaan Kementerian Kelautan dan Perikanan. Taman wisata perairan adalah kawasan konservasi perairan dengan tujuan untuk dimanfaatkan bagi kepentingan wisata perairan dan rekreasi seperti Taman Wisata Perairan Gili Matra yang berada di Provinsi Nusa Tenggara Barat. Dengan demikian maka TWP Gili Matra selain sebagai Kawasan konservasi juga dimanfaatkan untuk tujuan wisata.

Sebagai kawasan konservasi, TWP Gili Matra mempuyai dua target konservasi yaitu target biokologis dan target social, budaya dan ekonomi (BKKPN, 2021). Target bioekologis meliputi terumbu karang, lamun, mangrove dan sumberdaya ikan. Berdasarkan luas, terumbu karang mendominasi TWP Gili Matra yaitu 236,25 Ha, disusul ekosistem lamun dan mangrove secara berturut-turut yaitu 89,21 Ha dan 1,8 Ha (BKKPN, 2021). Sedangkan target social, budaya dan ekonomi berfokus pada nelayan, pelaku wisata, dan penduduk sekitar Gili Matra. 
Kedua target tersebut harus tercapai secara seimbang, namun kegiatan pariwisata maupun kegiatan lainnya seperti penangkapan ikan berpotensi untuk merusak ekosistem yang menjadi target bioekologi apabila kegiatan tersebut melebihi daya dukung. Menurut Yulianda et al. (2019) bahwa kegiatan penyelaman di Gili Matra telah melebihi kapasitas sehingga ancaman degradasi terhadap sumber daya semakin besar. Namun pada masa pandemi Covid19, jumlah wisatawan berkurang sekitar lebih dari 90\%, sehingga ancaman tersebut diduga bisa relative berkurang.

Oleh sebab itu, maka penelitian ini dilakukan untuk mengetahui kondisi terumbu karang di dalam zona inti dan zona lain, selama masa pandemi Covid-19. Hasil penelitian diharapkan dapat dijadikan dasar pengelolaan kawasan konservasi TWP Gili Matra.

\section{BAHAN DAN METODE}

\section{Waktu, Kondisi, dan Lokasi Penelitan}

Penelitian dilakukan pada tanggal 12- 13 Agustus 2021 pada pukul 10.00-15.00 WITA di perairan Gili Air, Taman Wisata Perairan (TWP) Gili Matra (Gili Meno, Gili Ayer dan Gili Trawangan, NTB (Gambar 1). Lokasi penelitian terbagi atas 2 titik stasiun pengambilan data, yaitu 1). Terumbu karang di Zona Inti, dan 2). Terumbu karang di Subzona Perikanan Berkelanjutan Karang. Koordinat posisi pada masing-masing stasiun disajikan pada Tabel 1.

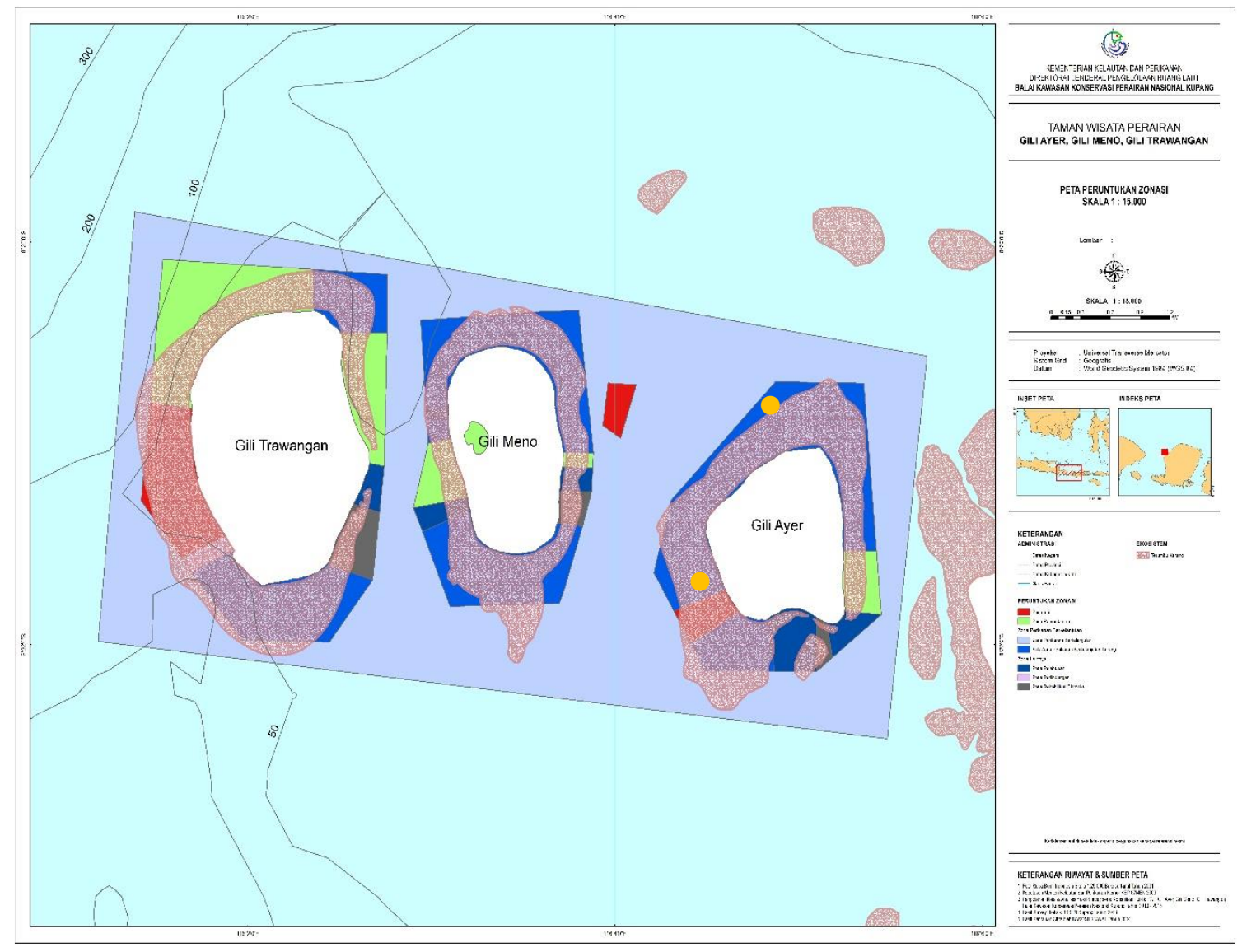

Gambar 1. Lokasi Penelitian, ( ) titik stasiun pengambilan data (Sumber Peta: Kepmen KP No.67/MEN/2009) 
Tabel 1. Koordinat posisi pada setiap stasiun penelitian

\begin{tabular}{lll}
\hline Zona & Koordinat & Keterangan \\
\hline \multirow{2}{*}{ Zona Inti } & "LS & $\begin{array}{l}\text { Stasiun Pengambilan data } \\
\text { terumbu karang }\end{array}$ \\
\hline Subzona Perikanan & "BT & "LS \\
Berkelanjutan Karang & "BT & $\begin{array}{l}\text { Stasiun Pengambilan data } \\
\text { terumbu karang }\end{array}$ \\
\hline
\end{tabular}

\section{Metode}

Metode Line Intercept Transect (LIT) (English et al., 1994) dengan penyelaman bawah laut dilakukan dengan membentangkan roll meter pada dasar perairan sepanjang $50 \mathrm{~m}$ (5.000 $\mathrm{cm}$ ) di titik stasiun pengambilan data (lihat Gambar 1). Selanjutnya, titik awal bentangan transek dicatat koordinatnya menggunakan GPS (Global Positioning System) dan depth gauge digunakan untuk estimasi kedalaman perairan. Jenis-jenis substrat penyusun dasar perairan yang bersinggungan dengan bentangan transek kemudian diidentifikasi dan dilakukan pencatatan, termasuk panjang singgungannya pada lembar data yang kedap air. Jenis/kategori substrat dasar perairan mengacu pada English et al. (1997) (Tabel 2).

Tabel 2. Jenis/kategori substrat dasar perairan

\begin{tabular}{|c|c|c|c|}
\hline \multicolumn{2}{|c|}{ Bentuk Petumbuhan (Life form) } & Kode & Keterangan \\
\hline \multicolumn{2}{|c|}{ Dead Coral } & DC & Karang yang baru mati, berwarna putih \\
\hline \multicolumn{2}{|c|}{ Dead Coral with Algae } & DCA & Karang mati yang ditumbuhi alga \\
\hline \multicolumn{4}{|c|}{ Hard Coral: } \\
\hline \multirow[t]{5}{*}{ Acropora } & Branching & ACB & Bercabang seperti ranting. \\
\hline & Encrusting & $\mathbf{A C E}$ & $\begin{array}{l}\text { Bentuk merayap, seperti Acropora yang } \\
\text { belum sempurna. }\end{array}$ \\
\hline & Submassive & ACS & Bercabang lempeng dan kokoh. \\
\hline & Digitate & ACD & Percabangan rapat seperti jari tangan. \\
\hline & Tabulate & ACT & Percabangan arah mendatar. \\
\hline \multirow[t]{8}{*}{ Non Acropora } & Branching & CB & Bercabang seperti ranting pohon. \\
\hline & Encrusting & CE & Bentuk merayap, menempel pada substrat. \\
\hline & Foliose & CF & Bentuk menyerupai lembaran. \\
\hline & Massive & CM & Bentuk seperti batu besar. \\
\hline & Submassive & $\mathbf{C S}$ & Bentuk kokoh dengan tonjolan. \\
\hline & Mushroom & CMR & Bentuk seperti jamur, soliter. \\
\hline & Millepora & CME & $\begin{array}{l}\text { Semua jenis karang api, warna kuning diujung } \\
\text { koloni. }\end{array}$ \\
\hline & Heliopora & CHL & Karang biru, adanya warna biru pada skeleton. \\
\hline \multicolumn{4}{|l|}{ Other Fauna: } \\
\hline \multirow{2}{*}{\multicolumn{2}{|c|}{$\begin{array}{l}\text { Soft Coral } \\
\text { Sponge }\end{array}$}} & SC & Karang dengan tubuh lunak \\
\hline & & SP & Contoh: Aaptos aaptos \\
\hline \multicolumn{2}{|l|}{ Zoanthids } & $\mathbf{Z O}$ & Contoh: Palythoa tuberculosa \\
\hline \multicolumn{2}{|l|}{ Others: } & OT & Anemon, teripang, gorgonian, kima \\
\hline \multirow[t]{5}{*}{ Algae } & Algae Assemblage & AA & Terdiri lebih dari satu jenis alga \\
\hline & Coralline Algae & CA & Alga yang mempunyai struktur kapur \\
\hline & Halimeda & HA & Alga dari genus Halimeda \\
\hline & Macroalgae & MA & Alga berukuran besar \\
\hline & Turf Algae & TA & Menyerupai rumput-rumput halus \\
\hline \multirow[t]{2}{*}{ Abiotic } & Sand & $\mathbf{S}$ & Pasir \\
\hline & Rubble & $\mathbf{R}$ & Patahan karang yang berserakan \\
\hline
\end{tabular}




\begin{tabular}{lccl}
\hline Bentuk Petumbuhan (Life form) & Kode & \multicolumn{1}{c}{ Keterangan } \\
\hline & Silt & SI & Lumpur \\
Water & WA & Kolom air /celah dengan kedalaman lebih dari \\
& & $50 \mathrm{~cm}$ \\
Rock & RCK & Tapakan karang termasuk batu kapur \\
& & DDD & Data tidak tercatat atau hilang \\
\hline
\end{tabular}

\section{Analis Data}

Analisa data terumbu karang dilakukan untuk mendapatkan persen penutupan setiap jenis substrat dasar perairan yang bersinggungan dengan transek. Persentase penutupan dihitung menggunakan rumus sederhana sebagai berikut (English et al., 1994):

$$
\mathbf{L i}=\mathbf{N i} / \mathbf{L} \times \mathbf{1 0 0 \%}
$$

Keterangan:

$\mathrm{Li} \quad=$ Persentase penutupan jenis $\mathrm{i}$

$\mathrm{Ni} \quad=$ Panjang total $(\mathrm{cm})$ penutupan jenis $\mathrm{i}$

$\mathrm{L} \quad=$ Panjang total transek

Mengacu pada English et al. (1994), persentase penutupan yang diperoleh kemudian dilakukan klasterisasi sebagai berikut:

- Excellent (Sangat baik), jika bernilai $75-100 \%$

- Good (Baik), jika bernilai 50-74,9\%

- Fair (Cukup), jika bernilai 25-49,9\%

- Poor (Buruk), jika bernilai 0-24,9\%

Indeks Mortalitas Karang (IMK) selanjutnya dihitung menggunakan rumus sebagai berikut (Gomez and Yap, 1988):

$$
\mathbf{I M K}=\mathbf{A} /(\mathbf{A}+\mathbf{B})
$$

Keterangan:

IMK = Indeks Mortalitas Karang

A $\quad=$ Persentase tutupan karang mati

B $=$ Persentase tutupan karang hidup

\section{HASIL DAN PEMBAHASAN}

\section{Subzona Perikanan Berkelanjutan Karang}

Kondisi tutupan dasar perairan di Subzona Perikanan Berkelanjutan Karang ini memiliki nilai persentase rata-rata dominansi karang keras hidup (hard coral) yang cenderung tinggi, yaitu $71 \%$. Persentase tersebut terdiri dari karang dengan enam jenis bentuk pertumbuhan, yaitu ACB, CB, CE, CF, CM dan CSM (Gambar 2). Karang Coral Branching (CB) memiliki nilai persentase tertinggi dibandingkan karang hidup lainnya, yaitu 36\%. Karang dengan bentuk pertumbuhan lainnya yang teramati adalah Acropora Coral Branching (ACB)(11\%), Coral Encrusting (CE)(6\%), Coral Foliose (CF)(5\%), Coral Massive (CM)(11\%) dan yang terkecil adalah Coral Submassive (CSM)(2\%). Jenis karang keras dengan bentuk pertumbuhan 
Coral Branching yang memiliki presentase tutupan rata-rata tertinggi adalah dari genus Porites sp.

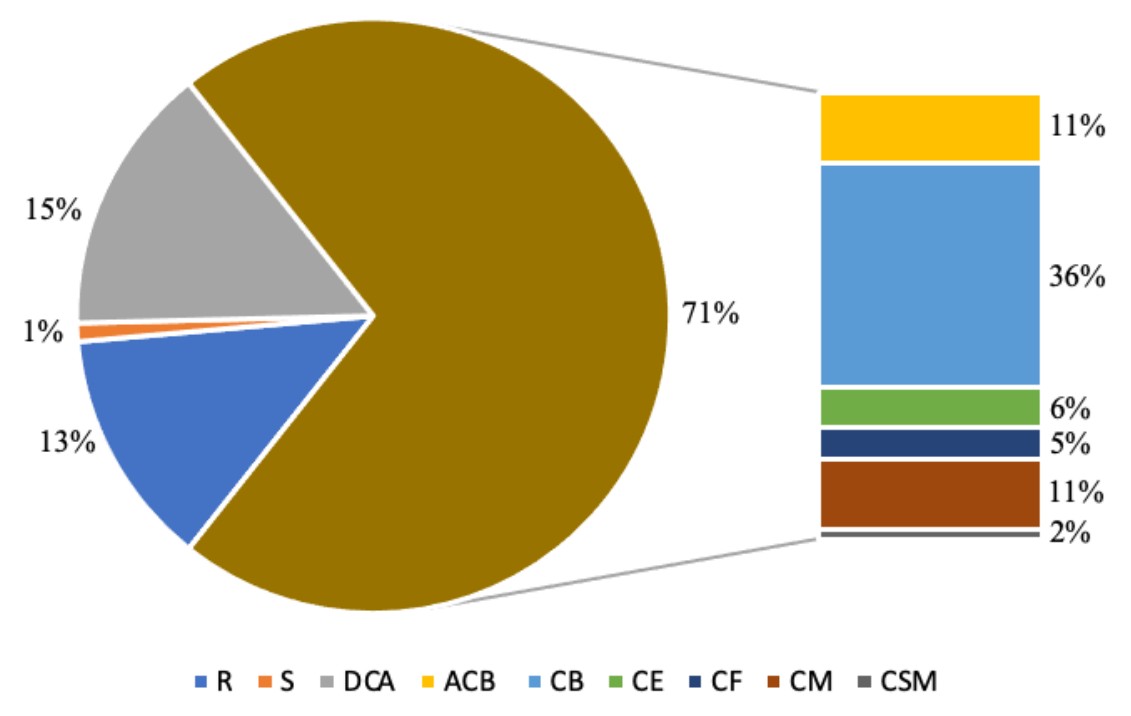

Gambar 2. Persentase tutupan dasar perairan di Subzona Perikanan Berkelanjutan Karang

Karang mati dalam bentuk Dead Coral Alga (DCA) atau karang mati yang ditumbuhi alga dan Rubble (R) atau pecahan karang memiliki akumulasi persentase rata-rata adalah $29 \%$. Keberadaan karang mati tersebut diduga akibat aktivitas perikanan yang tidak ramah dan merusak dimasa lampau. Namun, nilai tersebut tergolong lebih rendah dibandingkan dengan karang hidup. Nilai persentase rata-rata karang hidup pada zona ini yang sebesar $71 \%$ membuat terumbu karang di perairan ini dikategorikan baik. Kategori ini berada diantara nilai persentase 50-74,9\%. Indek Mortalitas Karang bernilai kecil, yaitu 0,28. Nilai tersebut mendekati 0 yang berarti terumbu karang memiliki rasio kematian yang rendah. English et al., 1997 menyatakan bahwa semakin mendekati nilai 1, maka Indeks Mortalitas Karang akan semakin tinggi. Keberadaan alga yang menempel juga menjadi indikasi bahwa karang tersebut telah mati dengan jangka waktu yang cukup lama.

\section{Zona Inti}

Kondisi tutupan dasar perairan di Zona Inti ini memiliki nilai persentase rata-rata karang keras hidup (hard coral) yang cenderung rendah, yaitu hanya $8 \%$. Persentase tersebut terdiri dari karang dengan tujuh jenis bentuk pertumbuhan, yaitu ACB, CB, CE, CF, CM, CMR dan CSM (Gambar 3). Karang Coral Encrusting (CE) memiliki nilai persentase tertinggi dibandingkan karang hidup lainnya, yaitu 3\%. Karang dengan bentuk pertumbuhan lainnya yang teramati adalah Acropora Coral Branching (ACB)(1\%), Coral Branching (CB)(1\%), Coral Massive (CM)(2\%) dan Coral Submassive (CSM)(1\%). Karang jenis Coral Foliose (CF) dan Coral Mushroom (CMR) memiliki nilai persentasi yang sangat kecil dan mendekati nilai 1 . 


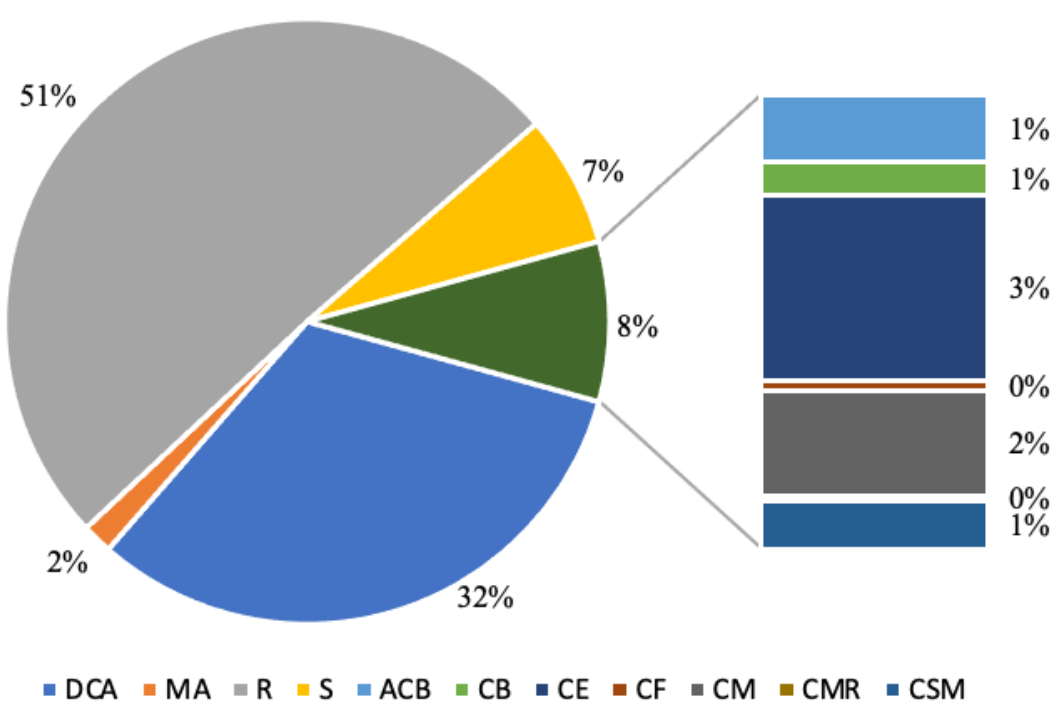

Gambar 3. Persentase tutupan dasar perairan di Zona Inti

Karang mati dalam bentuk Dead Coral Alga (DCA) atau karang mati yang ditumbuhi alga dan Rubble (R) atau pecahan karang memiliki akumulasi persentase rata-rata yang jauh lebih tinggi dan dominan disbandingkan Zona Perikanan Berkelanjutan Karang, yaitu adalah 92\%. Keberadaan karang mati tersebut diduga pula akibat aktivitas perikanan yang tidak ramah dan merusak dimasa lampau. Nilai persentase rata-rata karang hidup pada zona ini yang hanya sebesar $8 \%$ membuat terumbu karang di perairan ini dikategorikan buruk. Kategori ini berada diantara nilai persentase 0-24,9\%. Indek Mortalitas Karang bernilai sangat besar, yaitu 0,92. Nilai tersebut mendekati 1 yang berarti terumbu karang memiliki rasio kematian yang sangat tinggi.

Diskusi

TWP Gili Matra memiliki target konservasi berupa target sumberdaya (Bioekologis) yang meliputi ekosistem terumbu karang, mangrove, penyu, hiu karang dan pari manta. Selain target bioekologis, TWP Gili matra mempunyai target sosial seperti budaya dan ekonomi, dukungan dan partisipasi dalam pengelolaan, kepatuhan terhadap zonasi serta potensi alam sebagai pemberi jasa pariwisata (BKKPN, 2021). Kedua target tersebut diharapkan dapat berjalan seiiring melalui pengelolaan yang efektif.

Subzona Perikanan Berkelanjutan dan Zona Inti di Gili Air, TWP Gili Matra yang menjadi titik stasiun pengambilan data, adalah zona yang diputuskan melalui Kepmen KP No.67/MEN/2009. Luasan dari TWP ini mencapai 2.954 Ha (Dermawan et al., 2014). Menurut Permen KP No.31/Permen/2020 tentang pengelolaan Kawasan konservasi, zona inti adalah zona yang ditujukan untuk perlindungan mutlak terhadap target konservasi. Terdapat kategori zona lain, yaitu pemanfaatan terbatas yang ditujukan untuk kegiatan perikanan dan pariwisata secara berkelanjutan. TWP Gili Matra memiliki dua zona untuk kategori tersebut, yaitu Zona Perikanan Berkelanjutan dan SubZona Perikanan Berkelanjutan Karang. Zona lain yang juga terdapat di TWP Gili Matra adalah Zona Pemanfaaan.

Hasil penelitian yang dilakukan pada bulan Agustus 2021 menunjukkan hal yang menarik. Kondisi terumbu karang di Zona Pemanfaatan lebih baik dibandingkan dengan Zona 
Inti. Persentase karang hidup di zona inti hanya $8 \%$ sehingga tergolong jelek. Sedangkan di zona pemanfaatan mencapai $71 \%$ sehingga tergolong baik dan juga lebih baik dari kondisi terumbu karang di sekitar Gili Gede Lombok Barat (Buhari et al., 2021). Padahal, zona inti diperuntukkan sebagai zona no-take yang tidak membolehkan seluruh jenis kegiatan kecuali penelitian. Sedangkan zona pemanfaatan boleh dilakukan kegiatan pemanfaatan dengan menggunakan cara-yang ramah lingkungan. Sebab itu, maka tingkat gangguan antrophogenik terhadap ekosistem terumbu karang di zona pemanfaatan lebih tinggi dibandingkan dengan zona inti (Tarigan et al., 2016).

Penurunan persentase tutupan karang hidup di zona inti sudah tercatat dari penelitian sebelumnya. Pada tahun 2016, tutupan karang hidup sebesar 40\% yang tergolong dalam kondisi sedang, dan pada tahun 2016 menjadi 8\% setelah terjadi pemutihan (bleaching) (Setiawan et al., 2017). Jika bandingkan dengan hasil survei dapat dikatakan bahwa dalam rentang waktu 5 tahun, kondisi terumbu karang di zona inti tidak mengalami perbaikan. meskipun selama pandemic Covid-19 jumlah wisatawan berkurang. Karang hidup yang masih bertahan sampai saat ini diduga tidak mampu melakukan pemulihan (recovery) secara alami setelah mengalami pemutihan. Seperti yang dijelaskan Ampou et al. (2020) bahwa pemulihan ekosistem terumbu karang sangat tergantung pada kemampuan terumbu karang untuk tahan terhadap gangguan tanpa kehilangan struktur atau fungsi. Selain itu,, kualitas air yang buruk menyebabkan lambatnya terumbu karang pulih dari gangguan pemutihan (MacNeil et al., 2019).

Zona inti TWP Gili Matra dipilih dan ditetapkan berdasarkan kesepakatan antara pengelola dan masyarakat setempat. Zona inti yang ditetapkan di Gili Air bukan lokasi yang mempunyai kondisi terumbu karang terbaik (Setiawan et al., 2017) namun memiliki kawasan terumbu karang yang luas dan disepakati oleh masyarakat. Akan tetapi, tekanan terumbu karang bukan hanya karena anthropogenic tetapi juga karena faktor alam. Oleh karena itu, lokasi zona inti ini perlu dievaluasi lebih lanjut. Karena, salah satu faktor yang mempengaruhi keberhasilan dari suatu kawasan konservasi adalah lokasi zona inti yang dipilih kondisi biotanya masih mampu melakukan recovery (Buhari et al., 2011).

\section{KESIMPULAN}

Berdasarkan hasil penelitian dapat disimpulkan bahwa kondisi terumbu karang di zona pemanfaatan lebih baik daripada di zona inti Gili Air. Terumbu karang di zona inti tidak mampu melakukan recovery setelah terjadi bleaching meskipun jumlah wisatawan berkurang selama pandemic Covid-19. Oleh karena itu, lokasi zona inti ini perlu dievaluasi lebih lanjut agar efektifitas pengelolaan TWP Gili Matra dapat ditingkatkan.

\section{Ucapan Terimakasih}

Penelitian menggunakan dana PNBP Universitas Mataram tahun 2021 melalui skim penelitian peningkatan kapasitas. Untuk itu, penulis mengucapkan terima kasih kepada Lembaga Penelitian dan Pengabdian Masyarakat Universitas Mataram, Fakultas Pertanian dan BP3F Fakultas Pertanian. Ucapan terima kasih juga disampaikan kepada BKKPN Kupang khususnya Satker Gili Matra atas fasilitas dan bantuannya selama penelitian. 


\section{DAFTAR PUSTAKA}

Agardy, T., Bridgewater, P., Crosby, M. P., Day, J., Dayton, P. K., Kenchington, R., Laffoley, D., Mcconney, P., Murray, P.A., Parks, J. E., \& Peau, L. 2003. Dangerous targets? Unresolved issues and ide-ological lashes around marine protected areas. Aquatic Conservation: Marine and Freshwater Ecosystems 13:353-367

Ampou, E.E., Widagti, N., Nugroho, S.C., Sangadji, I.M. 2020. Status terumbu karang dan ikan karang di gili matra, Nusa Tenggara Barat. Ecotrophic. 14 (1): 14 -27.

BKKP Kupang, 2021. Kawasan konservasi gili matra. https://kkp.go.id/djprl/bkkpnkupang/page/2443-ekosistem-twp-gili-matra. Diakses pada tanggal 24 Februari 2021.

Buhari, N., Nessa, M.N., Ali, S.A., Jompa, J. 2011. Performance of community based marine protected area in Wakatobi Regency South East Sulawesi. Journal of Indonesian Coral Reefs 1 (2): 130 -136.

Buhari, N., Himawan, M, R., Jefri, E. 2021. Kondisi terumbu karang di perairan Gili Gede, Sekotong Lombok Barat. Jurnal Ilmu Kelautan Lesser Sunda 1(1): 24 - 28.

Burke, L., Selig, E., Spalding. M. 2002. Terumbu karang yang terancam di Asia Tenggara. Terjemahan Reefs at risk in Southeast Asia. World Resources Institute.

Dahuri, R., Rais, J., Ginting, S.P., Sitepu, M.J. 1996. pengelolaan sumberdaya wilayah pesisir dan laut secara terpadu. Pradya Paramita. Jakarta. 328 hlm.

Dermawan et al., 2014

English, S., Wilkinson C., Baker V. 1994. Line intercept transect. In: English S., Wilkinson C., Baker V. (eds) Survey manual for tropical marine resources. Australian Institute of Marine Science: Townsville.

English, S., Wilkinson C., Baker V. 1997. Survey manual for tropical marine resources. Australian Institute of Marine Science: Townsvile.

Gomez, E.D., Yap, H.T. 1988. Monitoring reef condition. In Kenchington R A., Hudson B E T (ed). Coral reef management hand book. UNESCO. Regional office for science and technology for South East Asia.

Keputusan Menteri Kelautan dan Perikanan No. 57 Tahun 2014 Tentang Rencana Pengelolaan dan Zonasi Taman Wisata Perairan Pulau Gili Ayer, Gili Meno, dan Gili Trawangan di Provinsi Nusa Tenggara Barat Tahun 2014-2034.

Kurniawan, F. 2017. Studi Resiliensi Spasial Pulau-Pulau Kecil: Kasus Kawasan Konservasi Perairan Nasional, Taman Wisata Perairan Gili Ayer, Gili Meno, Dan Gili Trawangan (Gili Matra), Nusa Tenggara Barat. Disertasi: Sekolah Pascasarjana Institut Pertanian Bogor: Bogor.

LIPI P2O. 2018. Status Terkini Terumbu Karang Indonesia 2018. LIPI.

MacNeil, M.A., Mellin, C., Matthews, S. et al. 2019. Water quality mediates resilience on the Great Barrier Reef. Nat Ecol Evol 3, 620-627 https://doi.org/10.1038/s41559-019-08323

McCook, L. J., Almany, G. R., Berumen, M. L., Day, J. C., Green, A. L., Jones, G. P., Leis, J. M., Planes, S., Russ, G. R., Sale, P. F., \& Thorrold, S. R. 2009. Management under 
uncertainty: Guide-lines for incorporating connectivity into the protection of coral reefs. Coral Reefs, 28(2), 353-366. https://doi.org/10.1007/s00338-008-0463-7

Peraturan Menteri Kelautan Dan Perikanan Republik Indonesia Nomor Per.17/MEN/2008 tentang kawasan konservasi di wilayah pesisir dan pulau-pulau kecil.

Peraturan Menteri Kelautan Dan Perikanan Republik Indonesia Nomor 57/Permen-Kp/2014 tentang perubahan kedua atas peraturan menteri kelautan dan perikanan nomor per.30/men/2012 tentang usaha perikanan tangkap di Wilayah Pengelolaan Perikanan Negara Republik Indonesia.

Peraturan Menteri Kelautan Dan Perikanan Republik Indonesia Nomor Per.67 /MEN/2009 tentang penetapan kawasan konservasi perairan nasional pulau gili ayer, gili meno, dan gili trawangan di Provinsi Nusa Tenggara Barat.

Pet-Soede, L. 2000. The effects of coral bleaching on fisheries in the Indian Ocean. Pp. 145178. In Socioeconomic assessment of the impacts of the 1998 coral reef bleaching in the indian ocean (S Westmacott, H Cesar, and L Pet-Soede, eds.). Resources Analysis and Institute for Environtmental Science (IVM). Report to the World Bank, African Environtmental Division for the CORDIO Programme.

Salm, R.V., Clark, J., Siirila, E. 2000. Marine and coastal protected areas: A Guide for planners and managers. IUCN. Washington DC.

Setiawan, F., Azhar, M., Tarigan, Muhidin, Hotmariyah, Sabil, A., Jessica P. 2017, Jurnal Kelautan Trunojoyo 10 (2): 147-161

Syms, C. and M. H. Carr. 2001. Marine protected areas: Evaluating MPA effectiveness in an uncertain world. Conference papers and proceedings Congresses.

Tarigan, S.A., Setiawan, F., Muttaqin, A., Pardede, S., Hotmariyah, A. Sabil. 2016. Laporan teknis: monitoring ekosistem terumbu karang taman wisata perairan gili matra tahun 2016. Wildlife Conservation Society-Indonesia Program. Bogor.

Wilkinson, C.R. 2000. Status of coral reefs of the world: 2000. Townsville (AU): Australian Institute of Marine Science. Australia. 363 p.

Yulianda, F. 2019. Ekowisata Perairan Suatu Konsep Kesesuaian Dan Daya Dukung Wisata Bahari Dan Wisata Air Tawar. Bogor: IPB Pres. 